\title{
Research on the Construction of Japanese Online Open Courses for Vocational Undergraduates Based on Information Technology
}

\author{
Yinhua Lin ${ }^{1, a}$

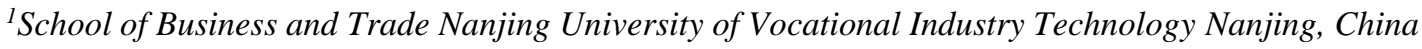 \\ alinyinhua1234@163.com
}

\begin{abstract}
The development of information technology provides rich solutions for the methods and models of modern education in colleges and universities. Online learning and VR technology have been widely utilized for the construction of Japanese courses in vocational universities. These technologies provide students a open platform for interaction learning which enhancing college students' cultural awareness and self-confidence. Finally, this paper concludes that current vocational undergraduate Japanese open course teaching status, and proposes corresponding solutions to the main problems. It is expected to provide a reference plan for curriculum teaching under the background of cultural confidence.
\end{abstract}

Keywords: curriculum ideology and politics; cultural awareness and self-confidence; Japanese teaching; open courses

\section{INTRODUCTION}

In 2018, the Ministry of Education of the People's Republic of China issued the "40 Articles of Higher Education in the New Era", Article 1 of the key measures mentioned: "Strengthen curriculum ideological and political construction. Comprehensively strengthen curriculum and professional ideological and political construction, and strengthen each teacher's awareness of morality. Integrating ideological and political education into each course" "promote the formation of an educating pattern in which professional and ideological and political courses are closely integrated, and the same direction is the same." "Opinions of the Ministry of Education on Deepening the Reform of Undergraduate Education and Teaching and Comprehensively Improving the Quality of Talent Cultivation" points out that "Ideological and political education shall be implemented throughout the entire process of talent training" and "Ideological and political construction of courses shall be regarded as the implementation of moral. The key link of the fundamental task of human beings is to insist on the unity of knowledge transfer and value guidance, and the unity of explicit education and implicit education, and fully explore the ideological and political education resources contained in various courses and teaching methods." From these newly issued national education policies, it can be seen that ideological and political education is no longer limited to one course but must be integrated with other professional disciplines in colleges and universities, leading and driving the entire staff to cultivate talents in an all-round and full process. In January 2017, the Shanghai Municipal Education Commission first proposed the concept of "Curriculum Ideological and Political". Some universities in Shanghai took the lead in exploring and trying to transform the traditional "Ideological and Political Courses" into "Curriculum Ideological and Political.", In practice, build a new pattern of "Three All-round Education". As a result, "curriculum ideology" came into being as an innovative educational concept, which was widely adopted by various universities and achieved good results.

General Secretary Xi Jinping repeatedly emphasized "cultural self-confidence" and pointed out that cultural self-confidence is a more fundamental, broader, and deeper force for realizing the great rejuvenation of the Chinese nation. Based on the new requirements of the new era, colleges and universities actively strengthen the cognition, inheritance, and development of college students' traditional Chinese culture. "Cultural confidence training" has become an extremely important part of "curriculum ideological and political" education. 
Therefore, how to effectively combine "curriculum ideology and politics" with foreign language teaching to enhance college students' cultural awareness and selfconfidence has become a question worth pondering, and it also provides new ideas and new ways for our future foreign language teaching.

\section{THE TRANSITION FROM "IDEOLOGICAL AND Political Course" to "Curriculum IDEOLOGICAL AND POLITICAL"}

Ideological and political theory courses in colleges and universities are the core courses for undergraduates to conduct Marxist theory education and socialist education with Chinese characteristics. As an independent subject system, ideological and political education is the foundation of all education and is to cultivate students' moral character, social responsibility, and patriotism. However, the "ideological and political courses" have always been in the difficult predicament of fighting alone, failing to compete with the general education courses, public basic courses, and professional courses in the college curriculum system (including philosophy and social science courses and natural science courses) Effective integration, the limitations have become increasingly prominent. The classroom is the main position and main channel of a college education. Classroom teaching is the main way of teaching and educating people. The speech of the general secretary shows that classroom teaching in the new era carries the dual role of knowledge transfer and value guidance. Ideological and political education should not be an independent course. The subject should break through the limitations of ideological and political classroom teaching content and teaching venues, fully excavate ideological and political education resources in professional curriculum teaching content, integrate ideological and political courses with professional classrooms, and give play to the silent moral education function of professional classroom teaching Integrating ideological and political education throughout the entire process of college education, taking Lide Shuren as the sacred duty of college teachers, realizing the creative transformation from "ideological and political courses" to "curriculum ideological and political", and truly achieving "full curriculum, full curriculum" The "Course Ideological and Political" education system of colleges and universities in the new era of orientation and full staff system.

\section{THE INTEGRATION OF "CURRICULUM IDEOLOGICAL AND POLITICAL" AND JAPANESE CLASSROOM TEACHING IN COLLEGES AND UNIVERSITIES}

Language is the carrier of culture, and training students' knowledge and skills and cross-cultural communicative thinking is the main goal of foreign language teaching. As an important part of the discipline of philosophy and social sciences, foreign language majors, although different languages belong to different language families, the history, society, politics, and culture of the country to which they belong, and their relationship and origins with Chinese are different, but due to the spread of foreign languages, It also completes the exchange of cultural ideas while exchanging information, including the absorption of foreign cultures and the self-identification and dissemination of traditional Chinese culture. One of the main functions of the ideological and political courses in the education of patriotism is the core values of socialism. Therefore, foreign language classrooms are undoubtedly one of the most suitable soils for ideological and political education.

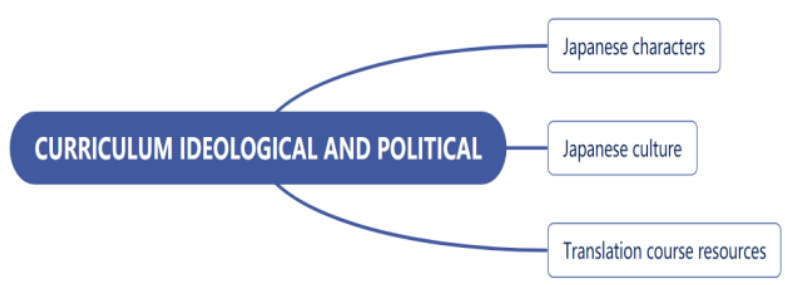

Figure.1 three main aspects on curriculum Ideological and Political

\section{1. "Curriculum Ideological and Political" and Japanese characters}

There was no written language in Japan in ancient times. As the history of the Sui Dynasty, the envoys of the Tang Dynasty and the merchants brought a large number of Chinese classics and Buddhist scriptures into Japan, the Japanese retained the original Chinese characters and created some Japanese characters. Besides, they used cursive and Chinese characters. Radical radicals created hiragana and katakana, respectively, and played the dual role of phonetic and ideographic. The ancient Chinese accents, Tang accents, Wu Chinese, and Min dialects also have a profound influence on Japanese pronunciation. In other words, in addition to the phonological Roman alphabet used for international communication, Japanese characters, hiragana, and katakana all have a deep relationship with Chinese. In the first lesson of "Basic Japanese", the above content is taught. Students use their familiar Chinese ability and Chinese cultural knowledge to understand and master the target language Japanese. Understanding the historical origins of the two countries is more conducive to language learning and enhances cultural awareness and culture. confidence. On the contrary, in modern times, due to Japan's political, economic, and technological progress, a large number of its translations of Western works have produced many new words.

New words about humanities and society in Japanese have become a possibility, such as "club", "romance", 
"science", "feudal" and "universe". Besides, Japanese terms related to classical skills have also spread to China, such as "Monument", "Tea ceremony", "Judo", "Bushido". These Japanese vocabularies introduced into China are well-known by Chinese Japanese learners and are conducive to Japanese learning. By introducing the origin of the vocabulary, it is conducive to cultivating students' cultural tolerance mentality. The two-way interactive communication path of Chinese and Japanese characters illustrates the differences between China and Japan. Historically, students will always identify, absorb and learn new knowledge with a broad perspective of openness and acceptance, and patriotism in their future Japanese learning. This is precisely the application of the concept of "curriculum ideology" to the elementary Japanese classroom. Examples in teaching.

\section{2. "Curriculum Ideology" and Japanese Culture}

Japanese professional courses pay attention to the cultivation of cultural awareness while imparting professional skills and knowledge, and explore the ideological and political education resources contained in professional courses, especially cultural resources, such as Japanese extensive reading, Japanese overview, Japanese conversation, and business Japanese courses. Many cultural contents, including the comparison of Chinese and Japanese cultures, the mutual influence of Chinese and Japanese cultures, etc., make full use of these cultural teaching resources to provide unique conditions for the realization of "curriculum ideology", while learning the target language culture while reflecting on the advantages of traditional Chinese culture, The key to promoting language cognition and learning with culture is to form habitual thinking: interpreting the language and cultural phenomena of the target language with familiar Chinese culture will help to acquire new knowledge and realize the integration of ideological and political education in foreign language professional classrooms. And penetration. Japan is an inclusive country. It is good at drawing on the strengths of Eastern and Western countries to create a unique Japanese culture with oriental, fusion, and innovative cultural characteristics. Taking Japanese festivals as an example, "Vernal Equinox" and "Autumn Equinox" are two solar terms in the twenty-four solar terms in China. They are days when the sun directly hits the equator. "Vernal Equinox" means the beginning of spring, and "Autumnal Equinox" means the beginning of autumn. The "Vernal Equinox" and "Autumn Equinox" in Japanese festivals are transmitted from China, respectively, to celebrate the spring planting and autumn harvest. These two festivals reflect the customs of traditional Japanese farming society. Such examples abound, illustrating the far-reaching influence of Chinese culture on Japanese culture, the strong penetration, dissemination, and influence of traditional Chinese culture, the profound historical origins of the two countries, and the enhancement of cultural awareness and self-confidence by looking at Chinese culture. Patriotism, thus achieving the educational purpose of "curriculum ideological and political".

\section{3. "Curriculum Ideological and Political" and Translation Course Resources}

"Japanese-Chinese Translation" is one of the main courses for senior majors. It aims at cultivating compound and practical Japanese talents to improve students' comprehensive language ability and social practice skills. In addition to theoretical knowledge and translation skills, the teaching content is more importantly translation practice training. Therefore, the selection of training content is very important. Xiu Gang pointed out that the translation practice of the political documents of the 19th National Congress of the Communist Party of China is the most vivid material for the translation practice of Chinese-to-Japanese translation, and its research is also the best topic for establishing Chinese-to-Japanese publicity and a Chinese voice. Combining the concept of "curriculum ideological and political", using national propaganda documents such as the report of the 19th National Congress of the Communist Party of China as translation course resources, from linguistics including the use of grammar and semantics to the mastery of translation strategies and skills; from rhetoric and literature, and writing styles Relationship introduction, to theoretical and logical reasoning and analysis, to combine translation theory with teaching practice, and combine professional skills knowledge with patriotic education. College students are the pillars of national construction in the new era. Through the study of national propaganda documents such as the report of the 19th National Congress of the Communist Party of China, they can improve the country's cultural soft power, increase national cohesion, cultivate national creativity, and cast the Chinese dream of the great rejuvenation of the Chinese nation.

Publicity translation is a special form of translation. It aims to let the world understand China in the context of globalization. It uses Chinese as the information source, English and other foreign languages as the information carrier, and uses various media as channels to use foreign people (Including all kinds of foreigners in China) as the object of communication activities. The Japanese translation of foreign propaganda must take into account the Japanese thinking style and cultural customs, in line with Japanese language expression and information acceptance. Improve the effect of communication and realize the purpose of cross-cultural communication. Through the teaching practice of Japanese translation of foreign propaganda materials, teachers guide students to use cross-cultural thinking, based on fully understanding the cultural similarities and differences between the two 
countries, to spread China's excellent traditional culture and accepting and learning foreign cultures as their responsibility to achieve both Interaction and integration of Chinese culture.

\section{TEACHING PRACTICE TO ENHANCE CULTURAL AWARENESS AND SELF-CONFIDENCE}

\subsection{The characteristics of "post-00" college students and their cultural awareness and self- confidence improvement dilemma}

Through the teaching of Japanese in recent years, we have discovered that current foreign language college students have "excessive personalization, insufficient common concepts, excessive information acquisition, insufficient information screening ability, excessive initiative, insufficient initiative, strong personal ability, and poor team awareness. It is characterized by the excessive depth of thinking, insufficient breadth of knowledge, excessive acceptance of foreign cultures, and insufficient self-consciousness of domestic culture. Moreover, in recent years, due to the popularization of smartphones, mobile media as an extension of network media has gradually become the main way for college students to obtain information, which has profoundly affected the improvement of college students' cultural awareness and confidence. In the mobile media environment, it is difficult to cultivate college students' cultural awareness and self-confidence. For example, the interactivity and fission of new media will cause college students to misread traditional culture and weaken college students' recognition of their own national culture;

Commercialization and entertainment have weakened college students' awareness of national cultural construction, resulting in students' reluctance to actively explore and spread the essence of Chinese culture; the decentralization and fragmentation of mobile media make college students' understanding of mainstream culture biased, resulting in social Misunderstanding of the mainstream culture of ism. In response to the above characteristics and problems, we have incorporated national culture and ideological and political content into the basic stage of Japanese teaching to promote the conscious generation and precipitation of foreign language college students' cultural consciousness, and thereby enhance cultural confidence.

\subsection{Feedback of teaching practice effect}

To solve the predicament of cultural awareness and self-confidence training mentioned in the previous article, the author incorporated the "pre-class presentation" link based on Chinese and Japanese culture in the basic Japanese teaching for the 2017 and 2018 levels. Presentation before class is one of the common teaching methods used by the majority of Japanese teachers. "PreClass Presentation" uses the "Zimmerman Autonomous Learning Theory", with "students" as the center and "teacher" as the assistance, to guide students in cultural thinking and exploration. "Autonomous learning" is an innovative and active learning method with students as the main body of learning. It corresponds to the traditional "receptive learning" and "mechanical learning", through students' active questioning and exploration, independent thinking and analysis, active practice and creation, etc. Methods to complete learning tasks and achieve learning goals. The presenters can combine freely, choose their topics, search for materials in advance, make PPT, and give oral speeches in Chinese or Japanese on stage, and then conduct interactive questions and answers with the audience. Through the "Pre-Class Presentation" exercises, college students' abilities in all aspects have been improved to a certain extent: (1) Corrected the three views and improved the ability of independent learning. (2) Enhance Chinese feelings, generate cultural consciousness, and enhance cultural self-confidence. (3) Improve the ability of thinking and innovation and language expression. (4) Deepen the understanding of Chinese and Japanese culture and broaden the horizon. (5) Cultivated certain research ability and teamwork spirit. (6) It stimulated interest in learning and enlivened the classroom atmosphere.

In the course of the open course, it can be seen that students have good visual effects in using multimedia courseware, and they have made great efforts in material collection and courseware production. Students have a wide range of interests, novel topics, clear thinking, and their own unique opinions in the conclusion. The students analyzed the pros and cons of Japanese culture, found some worthy lessons in Japanese culture, and put forward some suggestions for the development of our country. The disadvantage is that there are not many topics for comparison between China and Japan, and some publications only slightly mentioned the situation in China. In the future, students will be guided to discover Chinese elements in Japanese culture from the perspective of the history of Sino-Japanese exchanges.

\section{5. "CURRICULUM IDEOLOGICAL AND POLITICAL" AND JAPANESE TEACHING INTEGRATION MEASURES}

Exploring the ideological and political education resources in the Japanese curriculum, helping students solve their ideological confusion, and improving their ability to filter and analyze information. Traditional Japanese teaching, whether it is professional basic courses or professional skills courses, pays more attention to students' social and cultural background in Japan The unilateral introduction of knowledge, but there are still many teaching resources and methods that need 
to be explored urgently for Chinese-related social, historical and cultural knowledge, especially how to guide students to think and analyze problems with correct values.

Combine professional courses with the second classroom (extra-curricular practice) and informatization methods, and use ideological and political education resources to strengthen the cultivation of students' core literacy and competitiveness. Contemporary college students are active in their thinking, receive extensive information channels from the outside world, and have a concept of professional learning A large degree of change has also occurred. Therefore, through the combination of second classroom and information technology, we can grasp the students' professional learning outlook, and adjust the teaching design and methods accordingly to guide students to adopt a positive learning outlook. Adjust learning strategies; help students recognize and correct negative learning views, thereby improving learning effects.

For example, in terms of learning motivation, for freshmen who have just entered university, there is a considerable degree of vague learning motivation and unclear goals. Especially in recent years, foreign language majors are facing challenges in employment. Traditionally, they are less likely to be able to engage in foreign affairs and foreign trade. Many students say that relying only on foreign languages for future career planning is too simple, but they do not know how to study at university. Improve yourself in all aspects in four years. Therefore, the theories and policies concerning future career planning in classroom ideology and the improvement of the national foreign language ability to build the demand for high-level talents can all guide students through extracurricular lectures, extracurricular practice, MOOC, and other methods to help them clarify their motivations for learning. And transform the purely instrumental motivation of learning a foreign language into a fusion motivation that promotes knowledge, ability, and literacy.

\section{Conclusion}

The urgency and effectiveness of ideological and political in the classroom, especially in foreign language classrooms, have been widely concerned. Through a series of investigations and studies of the author, I found that ideology and politics enter the classroom, not only enter the classroom. As a basic educational concept, it must not only be rooted in the heart of every teacher, but also be integrated into the students' learning outlook, habits, and strategy construction. Through independent learning theory, classroom presentation, classroom discussion, extracurricular practice and information courses, etc., cultivate students' ability to think actively and acquire knowledge actively. In ideological and political learning, the traditional mode of "teacher speaking and students listening" must be changed, so that students will become knowledge explorers from passive receivers of knowledge. In the process of exploring knowledge, students will subtly and gradually enhance their cultural awareness and self-confidence, to truly realize the effective integration of "curriculum ideology" and Japanese teaching.

\section{REFERENCES}

[1] Juanjuan, Song, and W. Yanhong. "Teaching Research of "Curriculum Ideology and Politics" Into the Course of Probability and Mathematical Statistics." 2020 5th International Conference on Modern Management and Education Technology (MMET 2020) 2020.

[2] Rojasrimachi, Luisa Maria. "Teaching Culture Through Language And Literature: The Intersection Of Language Ideology And Aesthetic Judgment." Proquest Llc (2011):131.

[3] Shao, Xiao Yan. "Discussion on the Teaching Reform of Accounting Major from the Perspective of Curriculum Ideology and Politics." DEStech Transactions on Social Science Education and Human Science icesd(2020).

[4] Long-Ying, Zeng. "Research on the Application of Curriculum Ideology and Politics in Higher Vocational Mathematics." Sci-tech Innovation and Productivity (2020). 